\title{
ARTICLES
}

Submitted 06.30.2015. Approved 01.04.2016

Evaluated by double blind review process. Scientific Editor: Roberto Patrus

DOI: http://dx.doi.org/10.1590/So034-759020160304

\section{USING EXPERT JUDGMENTS TO RANK 45 LATIN AMERICAN BUSINESS JOURNALS}

\author{
Utilizando avaliações de especialistas para classificar 45 publicações latino- \\ americanas de negócios
}

\author{
Usando los juicios de expertos para ranquear 45 revistas latinoamericanas \\ de negocios
}

\begin{abstract}
This article presents the results of a study on the perception of quality of Latin American business journals based on the judgment of relevant experts - senior professors with knowledge of Latin American research and journals. Forty-five journals were included in the study. The highest perceived quality scores were given to Academia (CLADEA - Uniandes), RAE (Fundação Getulio Vargas), and Innovar (Universidad Nacional de Colombia). When perceived quality was weighted by awareness, Academia, LABR-Latin American Business Review (University of San Diego - Coppead), and Innovar had the highest scores. Results complement a recent study by Ruiz-Torres, Penkova, and Villafane (2012) that focused on management journals published in Spanish. Analysis of results suggests that language and branding have an effect on the perception of journal quality. Implications for editors/ publishers, tenure, promotion, research grant committees, and authors are provided.
\end{abstract}

KEYWORDS | Scientifics journals, ranking, Latin America, scientific production, business research.

\section{RESUMO}

Este artigo apresenta os resultados de um estudo sobre a percepção da qualidade de publicações latino-americanas de negócios com base nas avaliações de importantes especialistas - docentes de alto nível com conhecimento de pesquisas latino-americanas e publicações científicas. Quarenta e cinco publicações foram incluídas no estudo. As pontuações mais elevadas em qualidade percebida foram obtidas por Academia (CLADEA - Uniandes), RAE (Fundação Getulio Vargas), e Innovar (Universidad Nacional de Colombia). Quando a qualidade percebida foi ponderada pelo conhecimento (awareness), Academia, LABR-Latin American Business Review (University of San Diego-Coppead), e Innovar tiveram as maiores pontuações. Os resultados complementam um estudo recente realizado por Ruiz-Torres, Penkova, e Villafane (2012) focado em publicações de administração publicadas em espanhol. A análise dos resultados sugere que a linguagem e a marca exercem efeito sobre a percepção da qualidade da publicação. São apresentadas também implicações para editores, comitês responsáveis por promoções de docentes e verbas de pesquisa, e autores.

PALAVRAS-CHAVE / Publicações científicas, ranking, América Latina, produção científica, pesquisas de negócios.

\section{RESUMEN}

Este artículo presenta los resultados de un estudio sobre la percepción de calidad de revistas latino-americanas de negocios basada en las evaluaciones expertos - acadêmicos de alto nível con conocimiento de la investigación y publicaciones científicas en Latinoamérica. Cuarenta y cinco revistas fueron incluídas en el estúdio. Las evaluaciones más altas en calidad percibida lãs obtuvieron Academia (Cladea - Uniandes), RAE (Fundação Getulio Vargas), e Innovar (Universidad Nacional de Colombia). Cuando la calidad percibida fue ponderada por el conocimiento (awarenes) Academia, LABR- Latin American Business Review (University of San Diego - Coppead), e Innovar tuvieron las puntuaciones más altas. Los resultados complementan un estudo reciente realizado por Ruiz-Torres, Penkova y Villafane (2012) enfocado en las revistas de administración publicadas en español. El análisis de los resultados sugiere que el lenguaje y que la marca ejercen un efecto sobre la percpeción de calidad percibida de las revistas. Adicionalmente se presentan implicâncias para editores, comitês responsables de promociones de profesores, comitês de investigación, y para autores.

PALABRAS CLAVE / Revistas científicas, ranking, Latinoamérica, producción científica, investigación

\section{SERGIO OLAVARRIETA}

solavarrietas@gmail.com

Professor at Universidad de Chile, Facultad de Economía y Negocios Santiago, Chile en negócios. 


\section{INTRODUCTION}

The evolution of scientific communities and disciplines is normally related with the evolution of the journals concerned with them (Lehman, 2004). The study of journals is therefore an important area of research, both in specific disciplines and in the sociology of science and scientometrics (Adler \& Harzing, 2009). Journals are examined and assessed for their relevance or influence within a particular discipline, with the purpose of guiding researchers on where to publish or in order to assess the contribution of researchers and institutions based on the journals they publish (see, for example, García, RodríguezSánchez, \& Fernández-Valdivia, 2012; or Harzing \& Mijndhardt, 2015; Niemi, 1987, 1988).

Promotion and tenure committees often use journal rankings and lists for key decision-making, selection committees use rankings to assess candidates' potential productivity, and evaluation committees and deans determine pay increases and incentives according to journal rankings. Researchers also use journal rankings for literature reviews or meta-analyses (see, for example, the review by Nicholls-Nixon, Castilla, Sanchez-García, \& Pesquera, 2011 on Latin America Management Research based on journals included in the Financial Times ranking). Even national higher education and research foundations use rankings to choose institutions and researchers for fund allocation. Additionally, editors and editorial boards can use journal rankings to adjust or fine-tune their journal strategies (Shugan, 2003).

Journal rankings have a long history in the United States, where many of the most reputable journals are published. Some authors even suggest that rankings can affect journal visibility and awareness and that earlier rankings of US-based journals could explain their reputation. This tradition has extended to both Europe and emerging markets. In Australia, for example, the Australian Business Deans Association publishes its own Journal Quality List, which includes 2,767 worldwide journals with four different quality levels: $\mathrm{A}^{\star}(6.9 \%), \mathrm{A}(20.8 \%), \mathrm{B}(28.4 \%)$ and C (43.9\%) (see http://www.abdc.edu.au/pages/abdc-journalquality-list-2013.html). Harzing.com provides another interesting ranking, which combines and presents several rankings from around the world, including the Financial Times Ranking, the AERES ranking in France, the British Association of Business School Ranking (ABS), the Danish Ministry ranking, the University of Queensland ranking, and others (see http://www.harzing.com/ jql.htm).

The need for a ranking of business journals in Latin America is quite relevant. Previous research has concentrated on Latin American journals of other disciplines or on Ibero-
American business journals or papers published in Spanish (see Ruiz-Torres et al., 2012). Perception-based rankings are quite important since knowledge, paradigms, and future citations are affected by reputation (Petersen et al., 2014). Science and scientific status can be conceptualized as a social exchange process (Zinkhan, Roth, \& Saxton, 1992), and journal reputation affects the reputations of both individuals (researchers) and institutions (universities). This article aims to contribute to the Latin American business research community by providing initial evidence on a sample of peer-reviewed business journals published in Latin America.

\section{BUSINESS JOURNAL RANKINGS}

Several studies have established journal rankings in particular disciplines or geographical areas (e.g., Brown \& Huefner, 1994, in accounting; Currie \& Pandher, 2011, in finance; Hetzel, 2000, in France; Hult, Neese, \& Bashaw, 1997, in marketing; Zinkhan \& Leigh, 1999, in advertising). These rankings generally use two major methodological approaches, one based on expert judgments and one based on objective/quantitative indicators such as citations, cross citation patterns, references used, quality of authors (based on citations), or similar computations (Baumgartner \& Pieters, 2003; Collazo-Reyes, Luna-Morales, Russell, \& Pérez-Angón, 2008; Harzing \& Val, 2009; Mingers \& Harzing, 2007; Romero-Torres, Acosta-Moreno, \& Tejada-Gómez, 2013). Previous studies have indicated that both types of journal assessment show high correlations (Mingers \& Harzing, 2007).

In Latin America, business research is on the rise, albeit still at an earlier stage of development than other sciences. The evolution of business-related disciplines and journals in Latin America, however, has been affected by certain trends, e.g., accreditation entities, business school rankings, and national research councils have been strongly encouraging the use of Web of Science's (WOS) impact factors to assess research and university production, although WOS excludes most business journals published in Latin America and other emerging markets. Web of Science (previously known as ISI-Web of Knowledge) is a subscription-based scientific database, indexing, and citation service managed by Thomson Reuters. This trend and the lack of formal, independent assessment on the quality of Latin American business journals pose a significant threat both to these journals and to Latin American business research communities. Providing rankings for Latin American journals will therefore help university administrators and other institutions to maintain a more balanced perspective than the current 'ISI or nothing' premise. This is particularly important as a number 
of studies have shown that the Thomson Reuters WOS database has a bias against social sciences, certain fields of business, non-English-language journals, emerging market topics, and other valuable formats of academic publications such as books (see, for example, Adler \& Harzing, 2009).

This article uses a subjective perceptual approach, which is a very common starting point for journal assessment in most disciplines (Hult, Reimann, \& Shilke, 2009; Luke \& Doke, 1987). A recent study by Ruiz-Torres et al. (2012) focuses on peer-reviewed journals published in Spanish and includes business journals from Latin America and Spain, but excludes all Brazilian journals. Of the 55 journals included in that paper, only 18 matched those used in the present study. Another important difference is the expert database; all of the experts in the study of Ruiz-Torres et al. (2012) were professors who had published at least one article in the 55 chosen journals. In our study, the selection process was opinion-based to ensure representativeness across relevant countries and institutions as well as selected academics' knowledge of the Latin American market and business schools.

This study and the one by Ruiz-Torres et al. (2012) are a contribution to Latin America's business research community, as well as to organizations that support Latin American business journals, as both studies provide an external assessment of the familiarity and quality of these journals. Because the present study is a starting point, it may contain a few errors of coverage and biases that might be difficult to control for in this type of investigation. However, this drawback can be improved by means of future replications that include more journals, expand the expert pool, and add other quality variables and indicators.

\section{METHOD}

There are two key methodological decisions in this type of study: what journals to include in the sample and what judges or experts to select for the assessment of journals. The journals were selected using four data sources or directories: ISI Web of Science, SciELO, Latindex, and EBSCO. Journals included in at least two of these directories were preselected. An additional step was to identify business/management publications from major research universities in the region according to international rankings (Universidade de São Paulo, Brazil; Universidad Nacional Autónoma de México, Mexico; Universidad de Chile, Chile; Pontifícia Universidad Católica de Chile, Chile; Universidade Federal do Rio de Janeiro, Brazil; Universidad Nacional de Colombia, Colombia; Universidad de Buenos Aires, Argentina; Instituto Tecnológico y de Estudios Superiores de Monterrey,
Mexico). Finally, 45 journals were chosen for assessment in this study. Further studies can make selection adjustments using different criteria.

The selection of experts was critical for this ranking, and we used three specific criteria in accordance with the study of Brown and Huefner (1994): a) reasonable representation of countries (including Brazil); b) sound knowledge of the business research published in Latin America and beyond; and c) knowledge of the Latin American business school sector. To select the experts, we used the list of Latin American business schools that regularly appear in the América Economía rankings, and combined it with a list of schools from the SCImago report on the best research universities in Latin America. We thus compiled a list of about 50 schools and then visited their web pages to identify senior faculty members (both associate and full professors) and professors in administrative or editorial positions. We reviewed their CVs and selected those with recent publications or important streams of research. Then, we combined the resulting list with a review of the Web of Science in order to identify researchers affiliated with Latin American business schools with strong publication records, and complemented the list with the names of professors from major journals in countries with the highest representation in ISI publications over the past 25 years (Brazil, Chile, Mexico, Colombia, Venezuela, Argentina, Peru, and Costa Rica).

Data were collected through a survey administered by Qualtrics. Three waves of reminders were sent to the expert judges in order to increase response rate as much as possible.

\section{Expert selection}

In all, 210 experts were included in the initial sample and were requested to complete the survey through emails that were sent to them including a link to the survey site. A hundred and fifty of these professors looked at or began to complete the questionnaire, and 82 completed it, totaling a $39 \%$ response rate, which is high for a web-based survey and for the importance, hierarchy, and status of the experts selected.

Table 1 presents the descriptive statistics of the expert sample. Ninety-three percent of the responding professors hold a Ph.D.; $61 \%$ are full professors and $29 \%$ are associate professors; $62 \%$ participate on editorial or scientific journal boards; $61 \%$ have published more than ten peer-reviewed journal articles; and $48 \%$ have published more than five articles in journals included in the Web of Science (ISI Thomson Reuters) database. These statistics suggest that the experts in the sample have the relevant knowledge to judge the quality of Latin American business journals. 
Table 1. Expert sample descriptions

\begin{tabular}{|c|c|c|c|}
\hline Criteria & Category & Number & $\%$ \\
\hline Total responses & & 82 & 100 \\
\hline \multirow{4}{*}{ Final degree } & Ph.D. & 76 & 92.7 \\
\hline & Ph.D. (c) & 2 & 2.4 \\
\hline & Master & 3 & 3.7 \\
\hline & Other & 1 & 1.2 \\
\hline \multirow{4}{*}{ Rank } & Full prof & 50 & 61.0 \\
\hline & Associate & 23 & 28.0 \\
\hline & Assistant & 8 & 9.8 \\
\hline & Other & 1 & 1.2 \\
\hline \multirow{3}{*}{ Editorial board membership } & Yes & 51 & 62.2 \\
\hline & No & 24 & $29 \cdot 3$ \\
\hline & $\begin{array}{c}\text { No } \\
\text { response }\end{array}$ & 7 & 8.5 \\
\hline \multirow{6}{*}{$\begin{array}{l}\text { Number of peer-reviewed } \\
\text { journal articles }\end{array}$} & $30+$ & 19 & 23.2 \\
\hline & $20-29$ & 12 & 14.6 \\
\hline & $10-19$ & 19 & 23.2 \\
\hline & $5-9$ & 17 & 20.9 \\
\hline & $1-4$ & 10 & 12.3 \\
\hline & 0 & 1 & 1.2 \\
\hline \multirow{5}{*}{$\begin{array}{l}\text { Number of papers in WOS } \\
\text { (ISI) journals }\end{array}$} & $10+$ & 16 & 19.5 \\
\hline & $5-9$ & 23 & 28.0 \\
\hline & $1-4$ & 33 & 40.3 \\
\hline & 0 & 9 & 11.0 \\
\hline & NR & 1 & 1.2 \\
\hline \multirow[t]{2}{*}{ Gender } & Male & 63 & 76.8 \\
\hline & Female & 19 & 23.2 \\
\hline
\end{tabular}

Table 2 presents the sample's subject area representation. Strategy (23\%), marketing (21\%), finance (20\%), and management $\&$ human resource management (17\%) are the most highly represented areas, covering key general management and functional areas in the field.

Table 2. Subject area representation

\begin{tabular}{|c|c|c|}
\hline Subject areas & Number & $\%$ \\
\hline Strategy & 19 & 23.2 \\
\hline Marketing and markers & 17 & 20.7 \\
\hline Finance & 16 & 19.5 \\
\hline $\begin{array}{l}\text { Management, organization theory and } \\
\text { human resource management }\end{array}$ & 14 & 17.1 \\
\hline Economics and public policy & 4 & 4.9 \\
\hline Accounting and management control & 2 & 2.4 \\
\hline Management information systems & 1 & 1.2 \\
\hline Other & 5 & 6.1 \\
\hline No response & 4 & $4 \cdot 9$ \\
\hline Total & 82 & 100 \\
\hline
\end{tabular}

Four countries have the highest representation in the sample - Chile (22\%), Colombia (17.1\%), Mexico (13.4\%), and Brazil (13.4\%). This representation is consistent with the two other indicators of relevance in this study, i.e., the percentage of Business Schools in the 2013 America Economía ranking and the total production of ISI papers (e.g., Olavarrieta \& Villena, 2014), see Table 3. Additionally, nine professors from outside Latin America were included in the sample (11\%) in order to provide neutral, general opinions. They were invited to participate due to their consistent participation in Consejo Latinoamericano de Escuelas de Administración (CLADEA) and Business Association for Latin American Studies (BALAS), as well as in meetings and conferences, such participation indicating that they have a good knowledge of the field of Latin American business research. In consideration of all of the above, the sample of business school professors participating in this study should be considered as an expert and relevant sample for the purposes of this study. 
Table 3. Experts by country

\begin{tabular}{|c|c|c|c|c|c|}
\hline Country & Number & $\%$ & $\begin{array}{l}\text { Business schools in } \\
\text { AE } 2014 \text { ranking }\end{array}$ & $\begin{array}{l}\text { ISI papers (1988- } \\
\text { 2012) total* }\end{array}$ & $\begin{array}{l}\text { ISI Papers per } \\
\text { million people* }\end{array}$ \\
\hline Argentina & 5 & 6.1 & $4(9.5 \%)$ & 205 & 5.7 \\
\hline Brazil & 11 & 13.4 & $5(11.9 \%)$ & 1074 & 6.2 \\
\hline Colombia & 14 & 17.1 & $5(11.9 \%)$ & 236 & 5,9 \\
\hline Costa Rica & 3 & 3.7 & $1(2.4 \%)$ & 60 & 14 \\
\hline Ecuador & 1 & 1.2 & $3(7.15)$ & 12 & 0.9 \\
\hline Mexico & 11 & 13.4 & $6(14 \cdot 3 \%)$ & 435 & 4.5 \\
\hline Peru & 6 & $7 \cdot 3$ & $2(2.4 \%)$ & 76 & 3.0 \\
\hline Latin America & 73 & 89.0 & & & \\
\hline Australia & 1 & 1.2 & & & \\
\hline Canada & 1 & 1.2 & & & \\
\hline Spain & 2 & 2.4 & & & \\
\hline USA (\&PR) & 5 & 6,1 & & & \\
\hline Outside Latin America & 9 & 10.9 & & & \\
\hline Total & 82 & 100.0 & & & \\
\hline
\end{tabular}

* Author's survey and author's elaboration from Web of Science database

\section{RESULTS}

\section{General results}

The survey was relatively simple in this study and measured two key variables: journal awareness and perceived quality. Journal awareness represents the degree to which a particular journal is recalled by the sample of experts. High journal awareness implies that scholars have this journal in mind, which provides a general assessment of a journal's reputational value. Journal awareness was measured by asking the experts to indicate the top 5 Latin American journals in an open-end question. Table 4 shows the number of experts who mentioned each journal (Awar) and the awareness percentage (Awar1).

The second variable measured in the study was perceived quality, which is defined as the average perception of quality of a particular journal among the experts who evaluated it. The experts in the sample were asked to rate the quality of 45 journals using a 5-point scale (1-very poor, 2-poor, 3-neutral, 4-good, 5-very good). They were also asked to suggest potential journals to be included in a future list of high-quality Latin American business journals.
Ranking journals based on awareness alone or on quality alone is a common practice, but, as Oltheten, Theoharakis, and Travlos (2005) have pointed out, that practice can generate comparability problems. For example, if journal $A$ receives an average score of 5 (the best score) and journal $B$ receives a slightly lower average score of 4.9, journal A will be ranked above journal $B$, disregarding the fact that journal A may have been assessed by just one professor while journal $B$ may have received votes from all of the experts in the sample. It therefore seems reasonable to generate an index or measure that considers both quality and awareness. A relative simple measure is weighted quality, in which perceived quality is weighted by awareness. We computed weighted quality by multiplying each journal's perceived quality score by its awareness (Awar2 or awareness percentage). Thus, weighted quality helps in the assessment of journals with similar awareness or quality scores. However, since this indicator is heavily influenced by the composition of the sample, the ranking is presented using average perceived quality scores, and weighted quality is used to position journals with similar quality scores and provide an additional measure for journal editors and authors to assess journals. 
Table 4 shows the 45 Latin American journals included in our study ranked by their perceived quality scores. Academia-Revista Latinoamericana de Administración, published by CLADEA and Universidad de Los Andes-Colombia, and RAE-Revista de Administração de Empresas, published by Fundação Getulio Vargas (FGV/Brazil) share the first position on the list, followed by Innovar-Journal of Administrative Sciences, BAR-Brazilian Administration Review, and Trimestre Económico.

Table 4. Latin American business journals perceived quality rankings

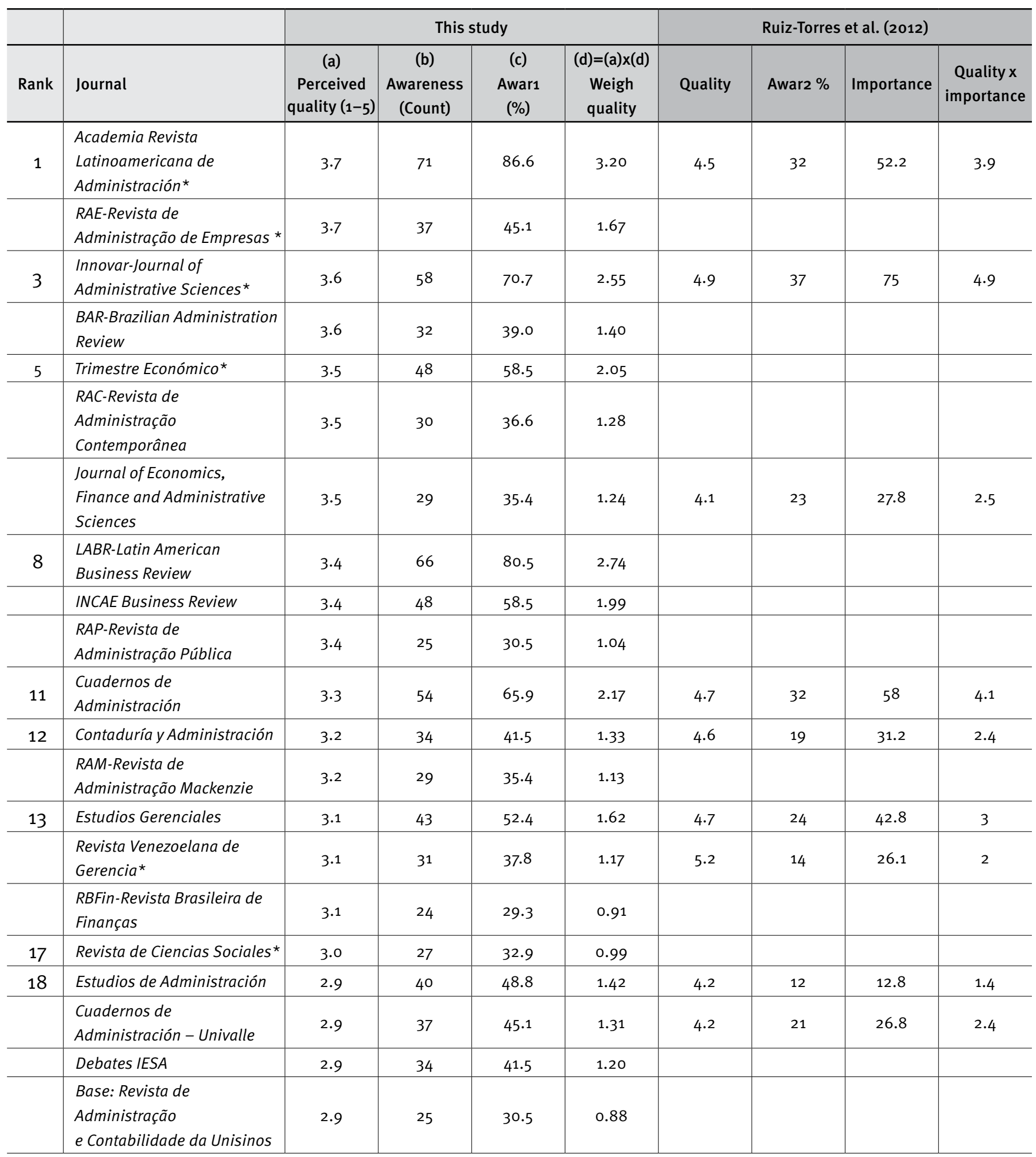


Table 4. Latin American business journals perceived quality rankings

(continuation)

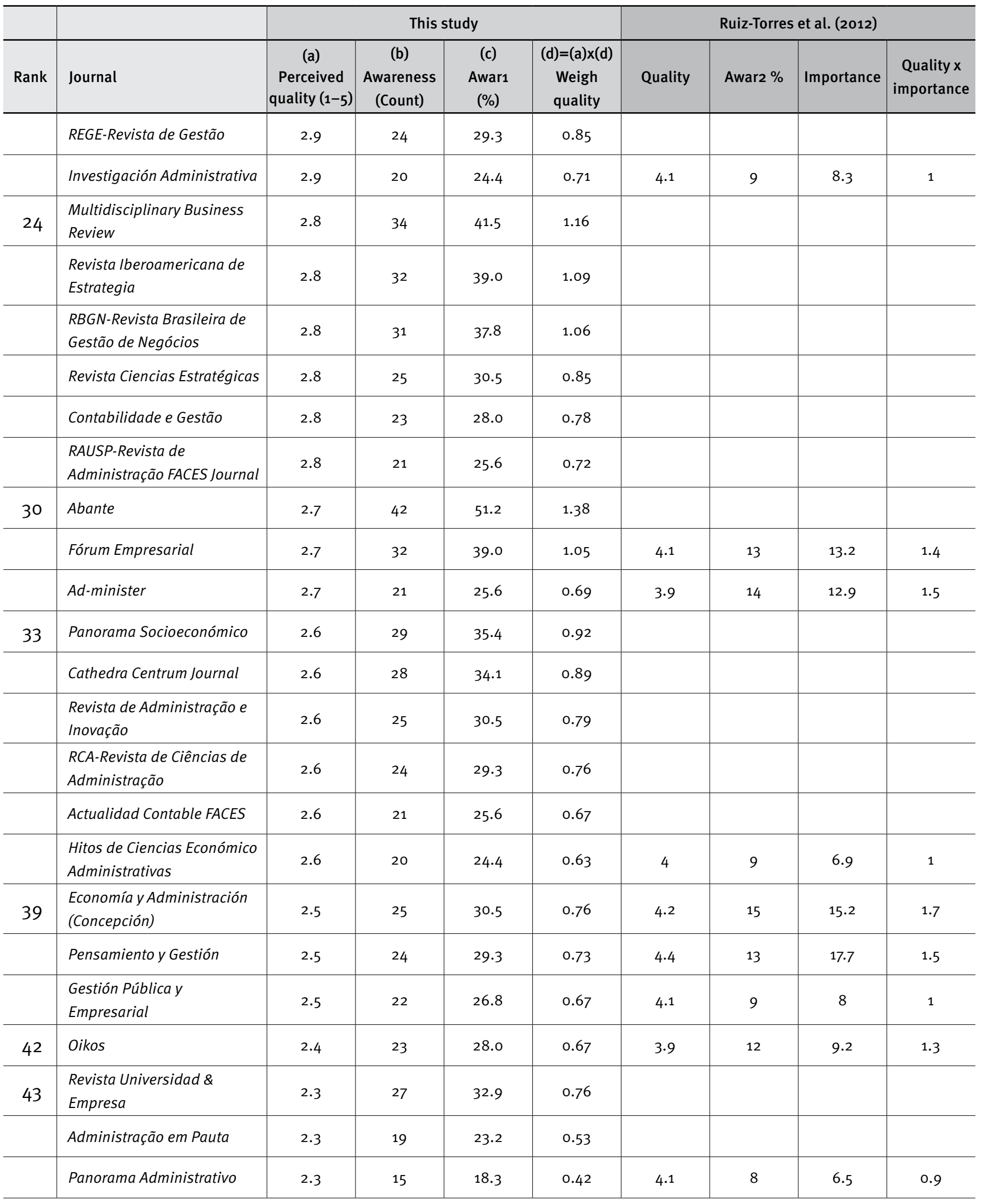

Note: *Journals included in the ISI database at the time of the survey 


\section{Comparison with Ruiz-Torres et al. (2012) and previous works}

This study differs from that of Ruiz-Torres et al. (2012) in a number of ways. The major difference is that their research focused on management journals published in Spanish in Ibero-America or other Spanish-speaking countries, while ours focuses on business journals published in Latin America in Spanish, Portuguese, or English. Therefore, the business journals covered in this study represent a broader scope of business-related disciplines and countries, including Brazilian journals which are significant in the context of Latin American business research. In fact, only 18 journals appear in both studies, and we reproduce the scores they had in the study of Ruiz-Torres et al. (2012) for comparison purposes. An additional difference is the sample of experts. In their study, the sample includes a large percentage of non-Latin American researchers (37\% from Spain and 6\% from the U.S., Canada, and Europe); moreover, within Latin America, Mexico is overrepresented, while Brazil is underrepresented, since the focus of their study was not on management journals in Portuguese. Furthermore, the inclusion of a larger percentage of junior faculty may affect the comparability of results. Nevertheless, there are certain journals that have strong awareness scores in both studies, which shows the importance of visibility and memory in this type of research. For these reasons, we believe that our study complements and provides new insights compared to previous studies on management journals (Ruiz-Torres et al., 2012) or Ibero-American journals (Aguado-Lopez, Becerril-García, Arriola, \& Martínez-Domínguez, 2014; Romero-Torres et al., 2013).

\section{Awareness and perceived quality versus weighted perceived quality}

A general analysis of the data results suggests that there are significant differences in awareness between journals, ranging from $18 \%$ to $87 \%$ for particular journals. Despite a positive correlation observed between perceived quality scores and awareness, we also found awareness heterogeneity among journals with similar perceived quality. For example, the awareness scores for the journals tied in the fifth position can vary from $35 \%$ to $59 \%$. This information is not considered in the general perceived quality scores. Therefore, we computed weighted perceived quality score using awareness percentage as the weight. When we ranked journals by these weighted scores, the list underwent changes. Thus, while Academia-Revista Latinoamericana de Administración was ranked first, LABR-Latin American Business Review, a journal published by UFRJ-COPPEAD (Brazil) and the University of San Diego
(USA) moved to the second place. Nevertheless, nine of the top ten journals remained on the same positions. These results show some indication that although quality is normally a key element in a journal's development strategy, editorial teams and boards should also consider working to increase awareness for their journals in the Latin American business research community. Age, journal name, country of publication, institution, and marketing efforts should also be considered.

\section{Other findings: The effects of indexation, branding, language, and institutional reputation}

An exploratory analysis of the findings might suggest potential determinants of perceived journal quality in Latin America. Indexation in international and globally prestigious journal indexes might be a critical factor. Four of the top five journals were indexed by ISI at the time of the study (from a total of six journals included in the Web of Science), and the fifth journal, LABR-Latin American Business Review, was indexed by Scopus.

Another interesting factor is the choice of journal brand name and language. Seven of the 45 journals included in the study have English (foreign) brand names. In fact, five of the top ten journals have English names, while none of the journals in the last ten positions have English or other foreign names. Some of the journals have a longer tradition, as with the LABR-Latin American Business Review. However the Journal of Economics, Finance, and Administrative Sciences is relatively new. It is published by ESAN, a Peruvian university and business school, and is the continuation of ESAN's Cuadernos de Difusión. Despite its newness, the journal appears among the top ten, and this change to an English name may have had an effect on the journal's position in the ranking. Another such example is the Multidisciplinary Business Review, a journal created recently by the Chilean Association of Business and Economics Schools (ASFAE). The effects of English (foreign) branding may derive from general stereotypes regarding scientific production and quality in English-speaking countries. English branding can also be a way to signal that the journal is published in the most common business research language (i.e. English), which suggests higher-quality articles.

Marketing research on foreign branding has suggested that users may derive additional meaning from names in a foreign language and that these effects are greater in the case of hedonic products compared to functional products (Leclerc, Schmitt, \& Dubé, 1994; Olavarrieta, Manzur, \& Friedmann, 2009). These effects may be generated by simple heuristics such as country stereotypes. Since high-quality journals have a high symbolic value, it is possible that experts may assign superior quality to 
journals with an English (foreign) name, particularly in the case of less known journals. The effect of language on journal citations (a key element for inferring the quality and reputation of a journal) has been previously mentioned in the literature (Guerrero-Bote \& Moya-Anegón, 2014), thus reinforcing our foreign languagebiased perceived quality hypothesis.

A third related explanation for perceptions of journal quality may be associated with the perception of the publishing institution, particularly with high-prestige business schools such as FGV (RAE), INCAE Business School (INCAE Business Review), or the Universidad de Los Andes in Colombia (Academia), as well as traditionally research-oriented schools such as the Universidad Nacional de Colombia (Innovar), or business school associations such as CLADEA (Academia), ANPAD (Brazilian association linked to two journals, BAR-Brazilian Administration Review, and RACRevista de Administração Contemporânea), BALAS (originally connected to LABR-Latin American Business Review), and Chilean ASFAE (Multidisciplinary Business Review). This idea is consistent with the study of Ruiz-Torres et al. (2012), which reported that the Ibero-American management journal with highest awareness was Universia Business Review, which combines the brand name of a powerful institution and website and the use of English rather than Spanish. Maciejowsky, Budescu, and Ariely (2009) suggest that researchers can be considered consumers of scientific production who can be influenced by their own perceptions of journals and/or authors and their symbolic value. Consistently, their perceptions of journals can be affected - like regular consumers - by naming and branding decisions. For example, they report that name ordering in articles may affect how readers perceive the contribution of each author. In this line of thought, article titles, the inclusion of 'academic stars' as co-authors, and the selection of English brand names and institutional brand names in the journal's title may affect the perceptions of symbolic value and journal quality by academics. Further factors that could also be exploited involve age, publishing house (university vs. international publishers such as Emerald, Taylor and Francis, Elsevier, etc.), and online web visibility.

\section{IMPLICATIONS}

This paper presents the results of a study on the perceptions that expert researchers in the region of Latin America have of the quality of Latin American business journals. Journal rankings are important for several purposes: they provide information to authors on potential research outlets; to publishers and editors who manage journals; to national and international agencies in their assessing of individual research production for grant allocation; and to university committees in their decisions regarding faculty promotion. These practices, which are already standard in prestigious business schools around the world, are now becoming more common in Latin American business schools due to national and international accreditation processes and increased competition (Bryant, 2013; Fragueiro \& Thomas, 2011). This paper complements a previous study by Ruiz-Torres et al. (2012) by focusing on business journals (not only management ones) and including 45 journals published in the region.

\section{Implications for journal editors and publishers}

Quality and reputation are relevant variables for journals to attract quality publications. Whether implicitly or explicitly, every journal (and publisher) aims at prestige and higher impact (Harzing, 2008). Journal quality is normally evaluated on a subjective basis by means of qualitative assessments by experts and the research community (Ruiz-Torres et al., 2012; Theoharakis, Voss, Hadjinicola, \& Soteriou, 2007) or by means of more quantitative methods such as citation counts and various impact factors (Mingers \& Harzing, 2007; Vastag \& Montabon, 2002; Zinkhan \& Leigh, 1999). Editorial boards and publishing house managers must establish strategies for journals in a very competitive environment (see, for example, Harzing, 2008; Harzing \& Adler, 2016). They have a number of levers they can use to increase journal reputation and rankings, such as inherent journal quality, journal awareness and knowledge, journal name and language, functional benefits to authors, and high-citation strategies. Below, we briefly discuss the following levers:

Inherent quality: Shugan (2003), a past editor of highly prestigious Marketing Science journal, advocates this strategy. He suggests that it is preferable to keep a journal strong by publishing timely articles on new trends or relevant problems, sophisticated methodologies, and influential research notes, rather than yielding to the temptation of adopting tricks to increase citations and rankings.

Awareness and knowledge: In today's competitive world, awareness goals may be as relevant as quality goals. Besides, they may be correlated. If the scientific community is not aware of a journal, that journal will not be sought out, and researchers will not publish in it or cite articles from it, thus reducing its visibility, indexation possibilities, and future perceptions of quality (Harzing, 2008).

Name and language selection: The use of foreign (i.e., English) language and institutional brand name in the journal name are potential drivers of perceived quality and visibility. Some journals in Latin America have English names (e.g., LABR-Latin American Business Research, and MBR-Multidisciplinary Business 
Research), while others use mixed names or change brand names for English ones as parts of their journal strategy. For example, Cuadernos de Difusión (ESAN Peru) changed its name to Journal of Economics, Finance and Management, and Revista de Gestão de Negócios (FECAP Brazil) uses Review of Business Management as a combined Portuguese-English name. The fact that five of the seven journals with foreign brand names in our sample were ranked among the top ten journals by the experts who participated in this study is an indication that the choice of a brand name and language can be an important lever of quality perception.

Functional benefits to authors: authors need to have their articles published, read, and cited. Therefore, journals that offer valuable, fast-paced review processes, easy editing and publishing processes, broad promotion, and access to published articles through different platforms might be as much in demand as higher quality journals with slow review processes and smaller audiences. Open access, digital publishing, and fast article turnover are new trends that need to be taken into account.

Citation growth strategies: Some journals specifically plan actions to increase impact factors and ranking (Shugan, 2003). Normally, these types of strategy involve changes in publishing policies (e.g. including review articles), the promotion of increased citations to the journal, special issues on hot topics (e.g. digital media), or opening the journal to authors in large and growing markets (e.g. Asia). Some of these actions have been criticized for artificially increasing citations and reducing the value of impact factors on the assessment of journals' quality (particularly self-citations and citation-exchange policies between journals). Thompson Reuters, the publisher of the Web of Science and Impact Factor statistics, has established a policy of dropping journals from its database if they are outliers in terms of those two practices. Recently, the American Society for Cell Biology launched the San Francisco Declaration on Research Assessment (DORA) (The American Society for Cell Biology - ASCB, 2012) to prevent the use of journal impact factors (JIF) to assess research quality due to certain deficiencies of JIF, e.g., that "Journal impact factors can be manipulated (or 'gamed') by editorial policy". Both Thompson Reuters and the DORA are ways to prevent the abuse of some of these strategies. However, increasing citations, as well as the relevance and visibility of journals, is critical for a journal's editorial policy and strategy.

Journal strategy reformulation is quite important given the changes the academic publishing industry is experiencing. For instance, the existing pressure by accreditation agencies and business school rankings has been forcing schools to concentrate on journals that are more prestigious or more visible. Furthermore, new open-access journals, pay-for-publishing models, and journals that have been recently acquired by global publishers use strategies that might be worth consideration by Latin American journal editors and editorial boards. Some of these new journals offer novel value propositions based on features like a fast review process and acceptance solely grounded on methodological soundness rather than on topic, regional, or highly theoretical relevance and replication. Latin American journal could consider including such features in their strategies.

\section{Implications for tenure and promotion committees and research grant committees}

University professors are regularly evaluated for purposes of salary increase, career promotion, and tenure decisions, and a relevant factor in such decisions is the assessment of their publication records (Hitt \& Greer, 2011), which includes the number of peer-reviewed publications and the quality of the journals in which they have published (based on perceived quality, indexation or citations). This is particularly common in U.S. and European business schools (Fleet, McWilliams, \& Siegel, 2000). Following this trend, the Australian Business Deans Council (ABDC) publishes a business journal quality list every 3-4 years, using four journal categories ( $A^{\star}, A, B$ and $C$, representing $6.9 \%$, $20.8 \%, 28.4 \%$, and $43.9 \%$, respectively, of the 2,767 journals included in the list). That classification has a strong bearing on the above-mentioned career-related decisions (see ABDC, 2013). Similarly, US-based business schools normally require a minimum number of publications in different categories (A, B and C journals) in order for associate or full professors to be granted tenure or be considered for a promotion (Fleet et al., 2000; Hitt \& Greer, 2011).

Requirements vary according to each school's emphasis, but good schools outside Latin America require professors to have published at least one A-journal article in the discipline and several B-journal articles to be eligible for promotions. In Latin American business schools, the use of journal indexations and impact factors as measures of quality and criteria for tenure and promotion has become widespread. ISI or WOS (Web of Science) is today the primary quality assessor, and ISI impact factors or quartiles are a relevant - sometimes the exclusive criterion for assessing an individual's research production. Even research agencies are now following this trend, particularly in engineering and economics-related disciplines where they are sometimes established as the only measurement for assessing research. The present study provides an additional element that can complement other criteria for decision-making regarding faculty promotion and research funding.

As Hitt and Greer (2011) have argued, academics working in emerging areas - or emerging markets, such as Latin America can face more difficulties to publish their research in mainstream 
outlets. The authors cite the field of strategic management as an example. This subfield, with its different or more multidisciplinary approaches and theoretical frameworks, was once on the fringe of the established management discipline and took almost 30 years to become established as a key sub-discipline of management. The creation of the Strategic Management Journal was critical in that process, and although it is now one of the top five journals in management, it was originally considered a low-level publication. Hitt and Greer (2011) call for more comprehensive evaluation approaches. The creation of a ranking of business journals in our region is key for that purpose.

\section{Implications for authors}

Authors often use international journal rankings to assess potential publication outlets, and the ranking provided in this study can help both Latin American and international researchers to evaluate these journals and select appropriate publications. Although there are discussions in the literature on the harm and good of journal rankings (Adler \& Harzing, 2009), economic principles indicate that providing more information should result in higher efficiency in the market. In this context, it is better to have multidimensional journal evaluations (Shugan, 2003), and this study contributes to that purpose. Therefore, in spite of journal rankings' limitations, we believe these rankings can play a relevant, positive role, particularly in a region that is beginning to grow and to become more involved in research production (Olavarrieta \& Villena, 2014). As Worrell (2009) affirms, journal rankings are here to stay.

\section{CONCLUSION}

Journal rankings are controversial, but at the same time, they are widely used and are relevant tools in universities and research agencies and institutions. Business research is evolving in Latin America due to major structural changes, such as a critical mass of Latin American business researchers, pressure and competition among Latin American business schools, international and national accreditation initiatives and regulations, increased research funds and grants, and increased GNP per capita, among others (Olavarrieta \& Villena, 2014). Therefore journal rankings are needed by different research stakeholders (promoters, producers, and consumers, etc.). This paper provides such a ranking based on the opinions of senior faculty from Latin America on business journals published in Latin America.

In the present study, the highest perceived quality scores were given to Academia (CLADEA-Uniandes), RAE (FGV), and
Innovar (Universidad Nacional de Colombia). When perceived quality was weighted by awareness, Academia, LABR-Latin American Business Review (University of San Diego, Coppead), and Innovar had the highest scores, while RAE appeared in the sixth place. These results complement a recent research by Ruiz-Torres et al. (2012) that focused on management journals published in Spanish (considering Ibero-American journals). Our analysis of the results of the present study suggests that language and branding have an effect on the perception of journal quality. With regard to journal editors and managers, our analysis suggests that they can improve journal quality perception by means of a mix of actions: improving the inherent quality of the articles included in the journal; increasing journal awareness and knowledge (by increasing distribution and promotion, online access, etc.); adjusting names and language selection (e.g. including an English translation of the journal's name, expanding language coverage to include English); providing more functional benefits to authors (like reduced review time and higher quality reviews); and promoting citations of the journal through better distribution, more relevant content, trending subjects, accepting review articles, among others.

We believe that the quality of the sample of experts who participated in this study ensures a sound and relevant ranking. Future studies can consider a more complex approach with several quality measures, including hard data indicators such as total citations or the $\mathrm{H}$-index (Romero-Torres et al., 2013) in combination with perceptions, as well as a wider range of independent variables driving those perceptions (Theoharakis et al., 2007). Thus, such future studies can provide a deeper assessment and understanding of the quality of business journals in Latin America.

\section{REFERENCES}

Adler, N., \& Harzing, A. W. (2009). When knowledge wins: Transcending the sense and nonsense of academic rankings. The Academy of Management Learning \& Education, 8(1), 72-95. doi:10.5465/ AMLE.2009.37012181

Aguado-Lopez, E., Becerril-García, A., Arriola, M., \& Martínez-Domínguez, N. D. (2014). Iberoamérica en la ciencia de corriente principal (Thomson Reuters/Scopus): Una región fragmentada. Interciencia, 39(8), 570-579.

Australian Business Deans Council. (2013). ABDC Journal Quality List 2013. Retrieved from http://www.abdc.edu.au/pages/abdc-journalquality-list-2013.html.

Baumgartner, H., \& Pieters, R. (2003). The structural influence of marketing journals: A citation analysis of the discipline and its subareas over time. Journal of Marketing, 67(2), 123-139. 
Brown, L. D., \& Huefner, R. J. (1994). The familiarity with and perceived quality of accounting journals: Views of senior accounting faculty in leading U.S. MBA programs. Contemporary Accounting Research, 11(1), 223-250. doi:10.1111/j.1911-3846.1994.tboo442.x

Bryant, M. (2013). International accreditations as drivers of business school quality improvement. Journal of Teaching in International Business, 24(3-4), 155-167. doi:10.1080/08975930.2013.860345

Collazo-Reyes, F., Luna-Morales, M. E., Russell, J. M., \& Pérez-Angón, M. A. (2008). Publication and citation patterns of Latin American and Caribbean journals in the SCl and SSCl from 1995 to 2004. Scientometrics, 75(1), 145-161. doi:10.1007/s11192-007-1841-6

Currie, R., \& Pandher, G. S. (2011). Finance journal rankings and tiers: An active scholar assessment methodology. Journal of Banking \& Finance, 35(1), 7-20. doi:10.1016/j.jbankfin.2010.07.034

Fleet, D. D. Van, McWilliams, A., \& Siegel, D. S. (2000). A theoretical and empirical analysis of journal rankings: The case of formal lists. Journal of Management, 26(5), 839-861. doi:10.1016/S01492063(00)00060-X

Fragueiro, F., \& Thomas, H. V. P. (2011). Strategic leadership in the business school. Cambridge, US: Cambridge University Press.

García, J. A., Rodriguez-Sánchez, R., \& Fernández-Valdivia, J. (2012). A comparison of top economics departments in the US and EU on the basis of the multidimensional prestige of influential articles in 2010. Scientometrics, 93(3), 681-698. doi:10.1007/S11192-012-0708-7

Guerrero-Bote, V. P., \& Moya-Anegón, F. (2014). Relationship between downloads and citations at journal and paper levels, and the influence of language. Scientometrics, 101(2), 1043-1065. doi:10.1007/s11192014-1243-5

Harzing, A. W. (2008). On becoming a high impact journal in international business and management. European Journal of International Management, 2(2), 115-118. doi:10.1504/EJIM.2008.017763

Harzing, A. W., \& Adler N. J. (2016). Disseminating knowledge: From potential to reality - New open-access journals collide with convention. Academy of Management Learning \& Education, 15(1), 140-156. doi:10.5465/amle.2013.0373

Harzing, A. W., \& Mijnhardt, W. (2015). Proof over promise: Towards a more inclusive ranking of Dutch academics in economics $\&$ business. Scientometrics, 102(1), 727-749. doi:10.1007/S11192-014-1370-Z

Harzing, A. W., \& Val, R. A. Van Der. (2009). A Google Scholar h-index for journals: An alternative metric to measure journal impact in economics \& business? Journal of the American Society for Information Science and Technology, 60(1), 41-46. doi:10.1002/ asi.20953

Hetzel, P. (2000). Where are we going? Perceptions of French marketing academics. Journal of Marketing Management, 16(7), 697-716. doi:10.1362/026725700784672953

Hitt, M. A., \& Greer, C. R. (2011). The value of research and its evaluation in business schools: Killing the goose that laid the golden egg? Journal of Management Inquiry, 21(2), 236-240. doi:10.1177/1056492611428721

Hult, G. T. M., Neese, W. T., \& Bashaw, R. E. (1997). Faculty perceptions of marketing journals. Journal of Marketing Education, 19(1), 37-52. doi:10.1177/027347539701900105

Hult, G. T. M., Reimann, M., \& Shilke, O. (2009). Worldwide faculty perceptions of marketing journals: Rankings, trends, comparisons and segmentations. Global Edge Business Review, 3(3), 1-23.
Leclerc, F., Schmitt, B., \& Dubé, L. (1994). Foreign branding and its effects on product perceptions and evaluations. Journal of Marketing Research, 31(2), 263-270. doi:10.2307/3152198

Lehman, D. (2004). Journal evolution and the development of marketing. Journal of Public Policy and Marketing, 24(1), 137-142.

Luke, R. H., \& Doke, E. R. (1987). Marketing journal hierarchies: Faculty perceptions 1986-1987. Journal of the Academy of Marketing Science, 15(1), 74-78. doi:10.1007/BF02721957

Maciejowsky, B., Budescu, D. V., \& Ariely, D. (2009). The researcher as consumer of scientific production: How do name-ordering conventions affect inferences about contribution credits. Marketing Science, 28(3), 589-598. doi:10.1287/mksc.1080.0406

Mingers, J., \& Harzing, A. W. K. (2007). Ranking journals in business and management: A statistical analysis of the Harzing dataset. European Journal of Information Systems, 16(4), 303-316. doi:10.1057/palgrave. ejis.3000696

Nicholls-Nixon, C. L., Castilla, J. A. D., Sanchez-García, J., \& Pesquera, M. R. (2011). Latin American management research: Review, synthesis, and extension. Journal of Management, 37(4), 1178-1227. doi:10.1177/0149206311403151

Niemi, A. W. (1987). Institutional contributions to the leading finance journals, 1975 through 1986: A note. The Journal of Finance, 42(5), 1389-1397. doi:10.2307/2328535

Niemi, A. W. (1988). Research productivity of American business schools 1975-85. Review of Business and Economic Research, 23(2), 1-17.

Olavarrieta, S., Manzur, E., \& Friedmann, R. (2009). Foreign branding: Examining relationship between language and international brand evaluations. INNOVAR: Revista de Ciencias Administrativas y Sociales, 19(35), 9-18.

Olavarrieta, S., \& Villena, M. (2014). Innovation and business research in Latin America: An overview. Journal of Business Research, 67(4), 489-497. doi:10.1016/j.jbusres.2013.11.005

Oltheten, E., Theoharakis, V., \& Travlos, N. G. (2005). Faculty perceptions and readership patterns of finance journals: A global view. Journal of Financial and Quantitative Analysis, 40(1), 223-239.

Petersen, A. M., Fortunato, S., Pan, R. K., Kaski, K., Penner, O., Rungi, A.,... Pammolli, F. (2014). Reputation and impact in academic careers. Proceedings of the National Academy of Science, 111(43), 15316 15321. doi: $10.1073 /$ pnas.1323111111

Romero-Torres, M., Acosta-Moreno, L. A., \& Tejada-Gómez, M. A. (2013). Ranking de revistas científicas en Latinoamérica mediante el Índice H: Estudio de caso Colombia. Revista Española de Documentación Científica, 36(1), 1-13.

Ruiz-Torres, A., Penkova, S., \& Villafane, C. (2012). Evaluación y clasificación de revistas arbitradas en el area de administración de empresas publicadas en español. Academia: Revista Lationamericana de Administración, 51(3), 48-64.

Shugan, S. M. (2003). Journal rankings: Save the outlets for your research. Marketing Science, 22(4), 437-441. doi:10.1287/ mksc.22.4.437.24904

The American Society for Cell Biology. (2012). DORA: San Francisco Declaration on Research Assessment. Retrieved from http:// www. ascb.org/files/SFDeclarationFINAL.pdf

Theoharakis, V., Voss, C., Hadjinicola, G. C., \& Soteriou, A. C. (2007). Insights into factors affecting Production and Operations Management (POM) journal evaluation. Journal of Operations Management, 25(4), 932-955. doi:10.1016/j.jom.2006.09.002 
Vastag, G., \& Montabon, F. (2002). Journal characteristics, rankings and social acculturation in operations management. Omega, 30(2), 109126. doi:10.1016/S0305-0483(01)00061-5

Worrell, D. L. (2009). Assessing business scholarship: The difficulties in moving beyond the rigor-relevance paradigm trap. Academy of Management Learning \& Education, 8(1), 127-130. doi:10.5465/ AMLE.2009.37012187
Zinkhan, G. M., \& Leigh, T. W. (1999). Assessing the quality ranking of the Journal of Advertising, 1986-1997. Journal of Advertising, 28(2), 51-70. doi:10.1080/00913367.1999.10673583

Zinkhan, G. M., Roth, M. R., \& Saxton, M. J. (1992). Knowledge development and scientific status in consumer-behavior research: A social exchange perspective. Journal of Consumer Research, 19(2), 282-291. doi:10.1086/209302 